University of Nebraska - Lincoln

DigitalCommons@University of Nebraska - Lincoln

To Improve the Academy

Professional and Organizational Development

Network in Higher Education

1998

The Role of Educational Developers in Institutional Change: From the Basement Office to the Front Office

Nancy Van Note Chism

Follow this and additional works at: https://digitalcommons.unl.edu/podimproveacad

Part of the Higher Education Administration Commons

Van Note Chism, Nancy, "The Role of Educational Developers in Institutional Change: From the Basement Office to the Front Office" (1998). To Improve the Academy. 401.

https://digitalcommons.unl.edu/podimproveacad/401

This Article is brought to you for free and open access by the Professional and Organizational Development Network in Higher Education at DigitalCommons@University of Nebraska - Lincoln. It has been accepted for inclusion in To Improve the Academy by an authorized administrator of DigitalCommons@University of Nebraska - Lincoln. 
Chism, N. V. N. (1998). The role of educational developers in institutional change: From the basement office to the front office. In. M. Kaplan (Ed.), To Improve the Academy, Vol. 17 (pp. 141-154). Stillwater, OK: New Forums Press and the Professional and Organizational Development Network in Higher Education. Key Words: change, change strategies, faculty development role, innovation, leadership, organizational climate, organizational development, planning, program assessment.

\section{The Role of Educational Developers in Institutional Change: From the Basement Office to the Front Office}

\section{Nancy Van Note Chism}

The Ohio State University

Educational developers can play a crucial role in helping colleges and universities respond to change. Among the roles they can play are researcher, assessment resource, friendly critic, messenger, translator, and coach. To perform these roles, developers need certain characteristics and special knowledge bases as well as enabling conditions within their environment. The current state of higher education may be calling for a paradigm shift in educational development as well.

For some time, there have been conversations, at POD meetings and other venues, about the role of educational developers (faculty, instructional, and organizational) in helping institutions of higher education respond to the changing educational environment. Educational developers, the argument goes, are ideally suited to helping administrators and faculty assess the situation and take educationally sound 
actions. Let's explore this idea in terms of the tasks that are involved, the role that the educational developer can take, the skills that the educational developer would have to have, and the enabling conditions that would have to prevail. Is a shift in thinking about educational development underway?

\section{Tasks}

At the heart of many organizational change theories, including current ideas on continuous quality improvement and the learning organization, is a very simple notion articulated by Kurt Lewin in the $40 \mathrm{~s}$-the idea of action research (see Lewin, 1957, or the summary in Carr and Kemmis, 1983). The basic notion is that if individuals in a work group are engaged in collecting and evaluating information about their situation, they are more likely to see the need for change and to generate direction for this change. They will be both informed and motivated. There are of course many different theories on how to stimulate organizational change, but the action-research-based models are ones that seem to me to be in line with facilitation by educational developers.

Within this framework, then, what are the organizational tasks and what are the tasks of the educational developer? My ideas are in the following chart.

Considering present effectiveness. Assessment data are featured at both the beginning and end of the steps in the chart, indicating a cyclic, rather than linear, process. As educational developers, we can play a central role in any change process by collaborating with faculty and administrators in promoting and implementing institutional assessment processes that provide continuous, rich data on effectiveness. By providing information on current assessment practices and consulting on the design and implementation of studies, we can be an important resource at this stage. Particular actions the developer might take range from bringing word of inititiatives such as the AAHE Assessment Forum and its publications and conferences to those entrusted with assessment, to informing a group studying the effects of distance education courses of findings made by such groups as the 
The Role of Educational Developers in Institutional Change

\begin{tabular}{|c|c|c|}
\hline Organizational Task & $\begin{array}{l}\text { How the Educational } \\
\text { Developer Can Help }\end{array}$ & $\begin{array}{c}\text { Role of the Educational } \\
\text { Developer }\end{array}$ \\
\hline $\begin{array}{l}\text { Consider present } \\
\text { effectiveness }\end{array}$ & $\begin{array}{l}\text { - Assist in articulating } \\
\text { assessment models } \\
\text { - Assist in implementation } \\
\text { of assessment methods }\end{array}$ & $\begin{array}{l}\text { Researcher } \\
\text { Assessment Resource }\end{array}$ \\
\hline $\begin{array}{l}\text { Embrace "hitches" - } \\
\text { problematic areas }\end{array}$ & $\begin{array}{l}\text { - Help decisionmakers } \\
\text { reflect on results of } \\
\text { assessment } \\
\text { - Create a community of } \\
\text { inquiry } \\
\end{array}$ & Friendly Critic \\
\hline $\begin{array}{l}\text { Generate possibilities for } \\
\text { change }\end{array}$ & $\begin{array}{l}\text { - Help create awareness of } \\
\text { new ways of thinking } \\
\text { about the work of higher } \\
\text { education }\end{array}$ & $\begin{array}{l}\text { Messenger } \\
\text { Translator } \\
\text { Impresario } \\
\text { Travel Agent } \\
\text { Networker } \\
\end{array}$ \\
\hline $\begin{array}{l}\text { Try out some new } \\
\text { possibilities }\end{array}$ & \begin{tabular}{|l|} 
- Provide process \\
consultation \\
- Contribute labor \\
- Give psychological support \\
\end{tabular} & $\begin{array}{l}\text { Nurturer } \\
\text { Partner } \\
\text { Coach }\end{array}$ \\
\hline $\begin{array}{l}\text { Collect data on the effects of } \\
\text { these changes }\end{array}$ & $\begin{array}{c}\text { - Assist with assessment (as } \\
\text { above) } \\
\text { The cyle repeats }\end{array}$ & $\begin{array}{l}\text { Researcher } \\
\text { Assessment Resource }\end{array}$ \\
\hline
\end{tabular}

Flashlight Project, thereby helping to ensure that learning outcomes are central to the study.

Embracing "hitches." As assessment results indicate areas for improvement or, better yet, challenge some assumptions about normal routines or ways of thinking about education, the educational developer can help the organization embrace these challenges rather than act defensively or ignore the information. By helping campus groups consider results constructively and in terms of incremental and practical steps that can lead to change, we can make the process of embarking on change less overwhelming. As educational developers, we are also in an ideal situation to create communities of inquiry related to the changes that could be made: for example, a special interest group exploring multicultural teaching or service learning. 
Generating possibilities for change. Even though most institutions are global in the connections they make with respect to scholarship, they often are unaware of possibilities for thinking about their educational mission differently. The educational developer on campus, then, is often the prophet of collaborative learning, learning communities, outcomes-based assessment, and other approaches that are under consideration nationally or internationally. The developer can disseminate informative print pieces that will stimulate awareness of possibilities for change, such as articles from Change magazine; clippings from The Chronicle of Higher Education; papers from the Pew Higher Education Roundtable or the Carnegie Foundation for the Advancement of Teaching; discussions from The National Teaching and Learning Forum, New Directions for Teaching and Learning, and the host of excellent books and periodicals that have arisen lately in the higher education arena. The developer can help to summarize this literature or provide briefings for faculty and administrators. The developer can also serve as "impresario," arranging for national experts and thinkers to come to campus, as well as helping administrators and faculty attend important national meetings or visit sites where important innovation is taking place.

Trying out some new possibilities. As institutions generate their own ideas for change or are inspired by others' ideas to try a similar innovation, the educational developer can help the institution with implementation. We can help a team think about process, support the work with enthusiasm and empathy for the difficulties involved in change, and actually perform some tasks. For example, if the change is to an outcomes-based curriculum in a given program, the developer can help the faculty develop a planning process, be supportive of the group with praise and willingness to listen and trouble shoot, and contribute personal or staff time to some activities, such as researching materials on outcomes models or helping to generate some language.

Collecting data on effects of changes. Once again, the educational developer can help in an assessment mode as the cycle of action, data gathering, and assessment begins again. We can serve as consultants by helping groups learn of assessment models that they can employ in studying the effects of the changes they have undertaken or 
by actually contributing labor in designing survey forms, conducting interviews, or analyzing results from a learning perspective.

\section{Characteristics Needed in Developers}

Facilitating the tasks involved in organizational change requires that educational developers possess certain skills, knowledge, and personal characteristics. My ideas on these characteristics are listed by role below:

\begin{tabular}{|l|l|}
\hline \multicolumn{1}{|c|}{ Role of the Developer } & \multicolumn{1}{c|}{ Characteristics Needed } \\
\hline $\begin{array}{l}\text { Researcher } \\
\text { Assessment Resource }\end{array}$ & $\begin{array}{l}\text { Knowledge of assessment strategies, } \\
\text { teaching and communication skills }\end{array}$ \\
\hline Friendly Critic & $\begin{array}{l}\text { Sincere concern, honesty, tact, courage, } \\
\text { communication skills, networking skills }\end{array}$ \\
\hline $\begin{array}{l}\text { Messenger } \\
\text { Translator } \\
\text { Impresario } \\
\text { Travel Agent } \\
\text { Networker }\end{array}$ & $\begin{array}{l}\text { Knowledge of national models and trends, } \\
\text { involvement in national network, } \\
\text { organization and communication skills }\end{array}$ \\
\hline $\begin{array}{l}\text { Nurturer } \\
\text { Partner } \\
\text { Coach }\end{array}$ & \\
\hline
\end{tabular}

As researchers and assessment resources, educational developers need to know how to think about assessment in postsecondary settings. While the expectation is not that every developer can be proficient in all of the research tasks that are involved in the various types of assessments that are possible, we should be aware of the range of designs and methods possible and how to get information on these strategies. We should know about print resources on program assessment in learning contexts, models at other institutions, and people on and off our own campuses who can be contacted when specific expertise is needed.

As friendly critics, educational developers need to have a sense of when and how our institutions can be challenged to deal with problems or shortcomings that assessments identify or that the national literature portrays. Such a role always requires tact and can even require 
courage. The message must be motivated by a sincere concern for the institution and its commitment to learning, rather than by a fascination with a fad or some personal gain. Communicating the message calls for the existence of a network of contacts who are willing to listen as well as access to key decisionmakers. It requires a reputation for credibility on the part of the educational developer.

As messengers and translators, educational developers need to be able to follow developments under discussion in the current literature and educational meetings and communicate these in a way that will be understood by their faculty and administrators, using the language and tone that is appropriate to the context. As impresarios, we need to be able to "book" visits with lecturers and consultants who will bring new ideas to our environments. As travel agents, we need to alert faculty and administrators about key conferences they should attend and campuses they should visit. Once again, networking skills are key.

Finally, as nurturers, partners, and coaches, we need to be personally centered, knowing our own capacity and believing in the capacity of our colleagues to recognize the need for change and be brave enough to experiment. We need to be generous in our support and praise for those who take on innovation.

\section{Enabling Conditions}

The tasks, roles, and characteristics needed for the educational developer to assist with change are daunting when they are enumerated. What quickly emerges is the realization that the educational developer who would take on these tasks must be working within a context of enabling conditions within the institution. Three of these are access, authority, and resources.

By access, I mean ready channels of communication with individual faculty, governance bodies, and curriculum/course design decisionmakers and participation on task forces and committees that deal with these issues. If educational developers are isolated or nested within several layers of organizational structure so that we do not have direct communication with decisionmakers, our influence is curtailed. Some indicators of access are: 
- being able to talk directly with decisionmakers (deans, academic affairs administrators, and the like) about new ideas or other business on teaching matters, being called regularly by such decisionmakers, or having a regular set of meetings scheduled with them to discuss new teaching matters

- being asked routinely to serve on committees on the state of teaching, the faculty reward system, the curriculum, or other teaching and learning matters

- being asked to present teaching issues to the Board of Trustees, the college/university senate, or other governance bodies

- being invited by chairs or faculty to present workshops or talks with instructors in the department

- being visited regularly by faculty and administrators

By authority, I mean credibility and respect from faculty and administrators. The literature portrays several types of authority, such as authority we gain merely by holding a certain title, authority we earn by our actions, and authority that is delegated to us by another. Authority is often defined as legitimate power. As educational developers, we are service-oriented, often focusing on our role as enablers rather than focusing on authority; yet, there are times when authority can be quite important in institutional change. If we do not have, by virtue of our position or personal characteristics, the power to reward, persuade, or impress, our potential influence is compromised. Some indicators of authority are:

- having a reputation for competence

- possesing a record of having exerted influence on the opinions of faculty and administrators

- being asked to be a visible partner in activities, such as a co-PI on a grant proposal, rather than the behind-the-scenes writer

- being asked to serve on high-level committees, rather than more routine ones

- having a relatively prestigious salary and title

By resources, I mean things needed to do good work, such as sufficient "think" time, staffing, tools (library, computer, and the like), 
and networking resources, such as travel funds. Some indicators of resources are:

- a reasonable staff-to-client ratio

- a travel budget that allows educational development staff to attend conferences and meetings where key ideas are discussed

- a library budget that allows educational development staff to obtain current literature

- time and funds for educational development staff to continue their own development

Very few educational developers have an overabundance of enabling conditions, particularly in the authority and resource areas; yet, we do not have to wait for enabling conditions to occur, but can actively take some steps to increase that possibility. First of all, we can try to align our actions with our institution's priorities. There are many teaching issues and needs that can be addressed at an institution: choosing those that are of key concern to the faculty and administrators will help garner support. Some goals, such as promoting service learning or initiating cluster courses, might be excellent but wrong for a given institution in terms of their timing. Listening to the pronouncements of key administrators; noting what kinds of pressures are coming from the legislature, students, parents, and other constituencies; and reading official documents are all important ways in which educational developers can assess what actions are likely to be most productive. This is not to say that sometimes educational developers will not have to try to initiate interest where there is none. That is often the case, but when the educational developer's agenda is closely linked with identified institutional priorities, supportive conditions are most likely to occur.

Second, we can develop a good track record for being helpful and knowledgeable. We can cultivate channels of communication, and by the usefulness of the information, ideas, and process facilitation we provide, improve our access, authority, and resources.

Cultivating self-confidence and an inner conviction about the importance of the work of educational development is another way in which we can stimulate the existence of enabling conditions. We often 
say about teacher enthusiasm, "Enthusiasm shows and so does its absence;" the same is true for our confidence and passion. If, as educational developers, we project a strong, centered presence, we are more likely to engender this in others. Ultimately, we cannot create supportive conditions for ourselves, but we can make it more likely that others will support us. When others have confidence in us, it is more probable that access, authority, and resources will come our way.

\section{A Shift in Emphasis for Educational Development}

The "paradigm" literature surrounds us these days. From Kuhn (1970) to Barr and Tagg (1995), many writers have discovered the usefulness of drawing contrasts between one way of thinking and another so different as to suggest a fundamentally different worldview. So why not us? Here is what our table might look like:

\begin{tabular}{||l|l|}
\hline \multicolumn{2}{|c|}{ Paradigm Shift for Educational Developers } \\
\hline From & To \\
\hline Individual consultation & \\
\hline Institutional view & Organizational development \\
\hline Cognitive focus & National/global view \\
\hline Providing answers & Wisdom focus \\
\hline Reactive stance & Improving questions \\
\hline Service & Proactive stance \\
\hline Basement office & Leadership \\
\hline
\end{tabular}

From individual consultation to organizational development. Clearly, if we are to help our institutions deal with the radical new developments that are on the scene today, we will have to focus at the organizational level. This is not to say that all work with individual faculty members - the kind of work that goes on quietly and behind the scenes - should stop; rather, it means that if we do not pay attention to the broader environment in which these faculty work, we will not have created the conditions under which they can be the excellent teachers we want them to be. For some time now, members of POD 
have called for more attention to organizational development. These calls are all the more compelling given the present situation.

From an institutional to national/global view. As educational developers, we have always focused on the places within which we work, trying to anticipate needs and provide necessary support. But when institutions become insular and defensive about demands and ideas in the external environment, it becomes necessary for change agents to become very familiar with the changing environment and more helpful to the institution in communicating information and ideas as well as supporting steps toward assessment and change. Even when there is a receptivity on the part of the institution, there is a need for people who can play the roles of messenger, translator, impresario, travel agent, and so on, mentioned above. Through technology and student population patterns, higher educational institutions are crossing state and national as well as pedagogical boundaries and they need help in exploring what these changes mean.

From a cognitive focus to a wisdom focus. Rooted as most educational developers are in learning and teaching, we have traditionally focused on cognition as a central phenomenon of concern. Even those of us who have used Bloom's taxonomy, constructivist theory, or other insights and models to move faculty beyond a focus on recall and content transmission to critical thinking and evaluation have routinely ignored the ethical, "big picture" dimensions of learning. What is this knowledge good for? How can we live together more peacefully, experience our existence more fully? These are the kind of questions we ask all too rarely. In an environment characterized by turbulence and moral crises, we need to rethink our focus accordingly.

From providing answers to improving questions. Educational developers have justifiably been proud of our service orientation and helpful attitude. When we get a request, we usually strive to satisfy the client, fetching print information, offering advice, or helping a group to come to agreement. Less often are we in the situation where we are helping frame the problem, in order to assess whether retrieving a certain kind of information would be answering a question that is not very useful. This kind of consultation requires both respected status, as mentioned above, but also the insights that a broader awareness of possibilities and much reflection can bring. Educational devel- 
opers, with their networking expertise and focus on reflection, have much to contribute in the area of problem framing.

From a reactive to proactive stance. Similarly, educational developers need to be a part of the agenda setting, not merely the agents responsible for parts of the implementation. For example, if the call is for building larger lecture halls or doing away with laboratory sessions, we need to question whether we should be advising architects on how to create large classrooms with movable seats or working with instructors on demonstration strategies rather than working with the policy groups that are generating such decisions. We can only take on these proactive roles, however, if we are aware of the long-term effects that decisions are likely to have and able to articulate these points within a broad knowledge of teaching and learning conversations nationally and globally.

From a service to a leadership orientation. By and large, educational developers have been background players. As mentioned above, most of us are service oriented, intrinsically motivated, and content to do good in a quiet and meaningful way. Our clients are most frequently the teachers, and our work is often done in confidence. When we think about how important it is to play a role in shaping the larger environment, however, it becomes clear that we have to work at higher levels of decisionmaking within the organization, where our service becomes leadership. Such leadership does not have to be highly visible or associated with power-although in some instances it might - but it does have to affect more directly the fundamental ways in which our institutions respond and act.

From the basement office to the front office. When I first started as a faculty developer, our unit was located in the basement of a nonacademic unit on the periphery of campus. That seemed symbolic of our status and way of working, unobtrusively dealing with the teaching issues that were at the fringes of the university fabric. More problematic than our physical location, though, was the lack of traffic between our office and those of the major decisionmakers - the offices of the president, the provost, the deans-both in terms of foot travel and phone or written communication. Over the years, I have seen an improvement in this traffic pattern, not only at my institution, but at others as well. A few educational developers have taken on titles such 
as assistant provost for faculty development; many units are more centrally located physically or on the organizational chart; and some developers are part of their president's cabinet or important advisory committees. These differences increase the chance that educational developers will be able to work for change that truly shapes the climate within which faculty work.

Whether these shifts deserve the designation of a new paradigm or simply represent renewed commitment to long-espoused goals, it seems to me that they are serious considerations for the work of educational development in the future. We have the opportunity to play important roles in transforming our institutions; we can embrace the opportunity, buoyed by our commitment to the mission of teaching and learning that we support so deeply.

\section{References}

Barr, R. B., \& Tagg, J. (1995). From teaching to learning: A new paradigm for undergraduate education. Change, 27(6), 13-25.

Carr, W., \& Kemmis, S. (1983). Becoming critical: Knowing through action research. Victoria, Australia: Deakin University Press.

Kuhn, T. S. (1971). The structure of scientific revolutions (2nd Ed.). Chicago: University of Chicago Press.

Lewin, K. (1957). Field theory in social science. London: Tavistock.

\section{Contact:}

Nancy Van Note Chism, Director

Faculty and TA Development

The Ohio State University

20 Lord Hall, 124 West 17th Avenue

Columbus, $\mathrm{OH} 43210$

(614) 292-3644

(614) 688-5496 FAX

chism.1@osu.edu

Nancy Van Note Chism is Director of Faculty and TA Development and Adjunct Associate Professor of Educational Policy and Leadership at The Ohio State University. She has served as President of the Professional and Organizational Development Network in Higher Education. She has been involved in directing or participating in several major funded projects, including the National Consortium on Preparing Graduate Students as College Teachers (Pew Charitable Trusts), Ohio State 
Cluster Preparing Future Faculty Program (Pew Charitable Trusts), and the Gateway Engineering Education Program (National Science Foundation). 